\title{
New species of Pyrrhulina (Teleostei: Characiformes: Lebiasinidae) from the eastern Amazon, Pará, Brazil
}

\author{
Lorena S. Vieira ${ }^{1,2}$ and André L. Netto-Ferreira ${ }^{2}$
}

A new species of Pyrrhulina is described based on 60 specimens from tributaries of the rio Amazonas: rio Anapu, rio Capim, rio Guamá and rio Xingu, and coastal drainages in the state of Pará, Brazil. The new species differs from all congeners by having the primary stripe (the horizontal stripe of dark pigmentation extending posteriorly from the snout) terminating at the distal edge of the opercle. In all other species of Pyrrhulina, the primary stripe is either restricted to the snout or continues beyond the head (i.e. at least the anteriormost four scales of the lateral line series).

Keywords: Color pattern, Freshwater fish, Pyrrhulininae, Taxonomy, Teleostei.

Uma nova espécie de Pyrrhulina é descrita baseada em 60 espécimes dos afluentes do rio Amazonas: rio Anapu, rio Capim, rio Guamá e rio Xingu, e drenagens costeiras no estado do Pará, Brasil. A nova espécie distingue-se de todas as congêneres por ter a faixa primária (faixa horizontal de pigmentação escura que se estende posteriormente do focinho) terminando na borda distal do opérculo. Em todas as outras espécies de Pyrrhulina, a faixa primária é restrita ao focinho ou continua além da cabeça (para incluir pelo menos as quatro escamas anteriores da série da linha lateral).

Palavras-chave: Padrão de colorido, Peixes de água doce, Pyrrhulininae, Taxonomia, Teleostei.

\section{Introduction}

The family Lebiasinidae includes 74 small species of fishes (16.0 mm SL up to maximum $250.0 \mathrm{~mm} \mathrm{SL}$ ) endemic to the Neotropical region (Weitzman, Weitzman, 2003; NettoFerreira et al., 2011; Fricke et al., 2019). Within Lebiasinidae, the subfamily Pyrrhulininae includes 45 valid species (Fricke et al., 2019) allocated among four genera, which are defined mainly by synapomorphies related to the oral area and cephalic laterosensory canals (Netto-Ferreira, 2010). Of these, the genus Pyrrhulina currently comprises 19 nominal species (Fricke et al., 2019) and needs revision (Géry, Zarske, 2002; Weitzman, Weitzman, 2003; Netto-Ferreira, Marinho, 2013). Netto-Ferreira (2010) corroborated the monophyly of the genus on the basis of four non-exclusive synapomorphies, the first two of which were traditionally employed to diagnose the genus (Géry, 1977): the presence of two series of functional premaxillary teeth, the lack of postcleithrum 3 , the dorsalmost, paired longitudinal series of scales not reaching posterior to the dorsal-fin origin, and the coronomeckelian bone approximately ten times shorter than Meckelian cartilage. During the early stages of a revisionary study of the genus, specimens of an undescribed species of Pyrrhulina were discovered in several collections, where they had been misidentified as Pyrrhulina brevis. The species is described herein.

\section{Material and methods}

Counts and measurements follow those proposed by Fink, Weitzman (1974) and Netto-Ferreira et al. (2011). All measurements were made point-to-point using calipers with $0.1 \mathrm{~mm}$ precision. Standard length (SL) is presented in $\mathrm{mm}$, all other measurements are presented as proportions of SL, except for head subunits, which are presented as proportions of head length (HL). Meristic data are given in the description, followed by the frequency of each count in parentheses and an asterisk indicating values for the holotype. Observations of teeth, vertebrae, supraneurals and procurrent caudal-fin ray counts were obtained from cleared and stained (c\&s) paratypes, prepared according to Taylor, Van Dyke (1985). Counts were made from the left side of specimens whenever possible. Vertebrae of the Weberian apparatus were considered four precaudal elements, transitional vertebrae (sensu Weitzman, 1962) were included in the count of precaudal vertebrae, and the fused PU1+U1 of the caudal region was counted as a single element (Netto-Ferreira et al., 2011). Patterns of circuli and radii were observed on scales sampled from the region between the lateral line series and the dorsalfin origin. Color pattern nomenclature follows Weitzman (1966). Basic descriptive statistics and statistical tests for meristic data were performed using SigmaStat for Windows

${ }^{1}$ Universidade Federal do Pará, Rua Augusto Corrêa, 66075-900 Belém, PA, Brazil. lolly.vieirasa@gmail.com, Dhttps://orcid. org/0000-0002-5971-2630 (corresponding author)

${ }^{2}$ Laboratório de Ictiologia, Departamento de Zoologia, Instituto de Biociências, Universidade Federal do Rio Grande do Sul, $91501-970$ Porto Alegre, RS, Brazil. alnferreira@gmail.com, Đhttps://orcid.org/0000-0002-3096-0411 
3.5 and SigmaPlot for Windows 10.0, Systat Software Inc. Institutional abbreviations are: ANSP (Academy of Natural Sciences, Philadelphia), CAS (California Academy of Sciences, San Francisco), FMNH (Field Museum of Natural History, Chicago), INPA (Instituto Nacional de Pesquisas da Amazônia, Manaus), LIA (Laboratório de Ictiologia de Altamira/Universidade Federal do Pará, Altamira), MBUCV (Museo de Biología de la Universidad Central de Venezuela, Caracas), MCNG (Museo de Ciencias Naturales de Guanare, Venezuela), MCP (Museu de Ciências e Tecnologia da Pontifícia Universidade Católica do Rio Grande do Sul, Porto Alegre), MHNLS (Museo de Historia Natural La Salle, Venezuela), MPEG (Museu Paraense Emilio Goeldi, Belém), MZUSP (Museu de Zoologia da Universidade de São Paulo, São Paulo), UFRGS (Universidade Federal do Rio Grande do Sul, Porto Alegre), and USNM (National Museum of Natural History, Smithsonian Institution, Washington).

\section{Results}

\section{Pyrrhulina capim, new species}

urn:1sid:zoobank.org:act:AB42697F-33FD-43BD-886BFD520ECFEC59

Fig. 1, Tab. 1

Pyrrhulina brevis (non-Steindachner). - Montag et al., 2008: 18 [checklist]; 28-30 [examined material: MPEG 10442, MPEG 10479, MPEG 11692]. - Silva-Oliveira et al., 2016: 125-142 [species list: inferred from known distribution]. — Ferreira et al., 2018: 553-557 [ecological study: inferred from known distribution].

Pyrrhulina filamentosa (non-Cuvier \& Valenciennes). - Montag et al., 2009: 245 [checklist]; 251 [examined material: MPEG 7627].

Pyrrhulina sp. - Montag et al., 2008: 30 [checklist, examined material: MPEG 10425]. - Raiol et al., 2012: 495 [checklist]; 498 [examined material: MPEG 10570].

Holotype. UFRGS 27300, 1, 54.4 mm SL, Brazil, Pará, Bragança, rio São José, $01^{\circ} 07^{\prime} 47^{\prime}$ 'S 46 49'13”W, 05 Feb 2012, J. C. O. Santana et al.

Paratypes. All from Brazil, from the basins of the rio Guamá, rio Capim: MPEG 4959, 1, $42.9 \mathrm{~mm} \mathrm{SL}$, Paragominas, igarapé Paraquequara, rio Guamá basin, 12 Jan 1992, M. Torres, J. Júnior; MPEG 6930, 3, 31.5-43.3 $\mathrm{mm}$ SL, Paragominas, igarapé Paraquequara $03^{\circ} 16^{\prime} 05^{\prime} \mathrm{S}$ $47^{\circ} 46^{\prime} 05^{\prime \prime}$ W, 16 Apr 2003, A. B. Sousa, V. S. E. Sena; MPEG 7385, 1, $21.2 \mathrm{~mm}$ SL, Paragominas, igarapé Paraquequara, 0314'50"S 4745'40”'W, 17 Dec 2003, A. B. Sousa, V. S. E. Sena; MPEG 7438, 1, $28.7 \mathrm{~mm}$ SL, Paragominas, igarapé Cachoeirinha, 18 Dec 2002, A. B. Sousa, V. S. E. Sena; MPEG 7500, 1, 47.9 mm SL, Paragominas, igarapé Paraquequara, $03^{\circ} 16$ '40"S 4743'53'W; MPEG 7502, 1,
$28.7 \mathrm{~mm}$ SL, Paragominas, igarapé Potiritá, $03^{\circ} 12^{\prime} 13^{\prime}$ 'S 47³9'52”W, 16 Dec 2002, A. B. Sousa, V. S. E. Sena; MPEG 9414, 6, 14.7-29.6 mm SL, Barcarena, rio Arienga, 01³8'0”S 4843’00”W, 26 Mar 2002 A. B. Sousa, V. S. E. Sena; MPEG 9417, 2, 28.0-33.9 mm SL, Paragominas, igarapé Paraquequara, $03^{\circ} 15^{\prime} 18^{\prime \prime} \mathrm{S} \quad 47^{\circ} 45^{\prime} 13^{\prime \prime} \mathrm{W}, 14$ Dec 2002, A. B. Sousa; MPEG 9424, 36, 12.6-41.9 mm SL, Paragominas, igarapé Paraquequara, 0316'40"S 4743'53”W, 14 Dec 2002, V. S. E. Sena; MPEG 9427, 2, 47.2-47.6 mm SL, Paragominas, Guamá-Capim system, rio Cachoeirinha, $03^{\circ} 12^{\prime} 42^{\prime \prime} \mathrm{S} 47^{\circ} 45^{\prime} 36^{\prime \prime} \mathrm{W}, 12$ Apr 2003, A. B. Sousa; MPEG 9555, 1, 19.3 mm SL, Tomé-Açu, 02²5'11”S 48 $12^{\prime} 13^{\prime \prime} W, 1$ Jul 2005, A. B. Sousa; MPEG 9560, 1, 16.7 mm CP; MPEG 9567, 4, 26.0-42.4 mm SL, Paragominas, igarapé Candiru, 02 $51^{\circ} 51^{\prime \prime S} 47^{\circ} 30^{\prime} 50^{\prime \prime} \mathrm{W}, 28$ Jun 2005, L. F. A. Montag; MPEG 9571, 2, 21.9-23.2 mm SL, Concórdia do Pará, igarapé Cajueiro, $02^{\circ} 03^{\prime} 06^{\prime}$ 'S 4753'09”W, 5 Sep 2005, A. B. Sousa, D. G. Oliveira; MPEG 9574, 4, 15.3$22.8 \mathrm{~mm}$ SL, Tomé-Açu, igarapé Timboteua, 0251'59"S 48 14'38”'W, 29 Jun 2005, A. B. Sousa et al.; MPEG 9575, 1, 32.5 mm SL, Tomé-Açu, igarapé Marupaúba, 02 ${ }^{\circ} 13^{\prime} 19^{\prime \prime S}$ $48^{\circ} 08^{\prime} 14$ ”'W, 1 Jul 2005, A. B. Sousa, D. G. Oliveira; MPEG 9585, 12, 39.6-49.7 mm SL; 2 c\&s, 43.3-49.8 mm SL, Tomé-Açu, igarapé Anuerazinho, 02³2'39”S 48 16'10”W, 30 Jun 2005, A. B. Sousa; MPEG 10570, 2, 37.2-41.5 mm

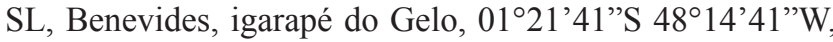
6 May 2006, M. B. Mendonça; MPEG 12128, 5, 16.7-26.9 mm SL, Benevides, igarapé Taiassuí, 20 Mar 2006, L. F. A. Montag; MPEG 16188, 23, 12.4-32.8 mm SL, Barcarena, rio Tauá, 01³6'00”S 4843’00”W, 21 Nov 2001, W. B. Wosiacki; MPEG 18274, 1, $45.0 \mathrm{~mm}$ SL, Ourém, igarapé da Loura, 01³2'37'S 4705'54'W, 16 Nov 2009, B. F. Pamplona; MPEG 21405, 1, 44.6 mm SL, Mãe do Rio, igarapé da Bicheira, $02^{\circ} 03^{\prime} 31^{\prime \prime} \mathrm{S} 47^{\circ} 25^{\prime} 51^{\prime \prime} \mathrm{W}, 24$ Oct 2010, P. Gerhard; MPEG 23516, 1, 26.0mm SL, Paragominas, 0315'12"S 4747'02"W, 8 Feb 2012, Alberto Akama; MPEG 29265, 2, 42.9-56.5 mm SL, Barcarena, Arienga I, 01³6'54”S 4844'03”'W, 18 Dec 2015, E. Reis, J, Vilar; MPEG 32950, 2, 24.8-33.5 mm SL, Barcarena, Tauá III, 0135'44”S 4843'13”W, 17 Dec 2015, E. Reis, J, Vilar. All from Brazil, Coastal drainages of the Amazon Estuary Pará, Bragança: UFRGS 25559, 13, 39.6-58 mm SL; 5 c\&s, 44.2-53.3 mm SL, same data as holotype; UFRGS 25560, 1, 54.2 mm SL, Capitão Poço, fazenda Cachoeira, 01 38 '59”S 4706' 03”W, 02 Feb 2012, J. C. O. Santana et al.; UFRGS 25562, 3, 43.8-55.9 mm SL, Bragança, near the Colônia Prati, $01^{\circ} 05^{\prime} 57^{\prime \prime S} 46^{\circ} 48^{\prime} 45^{\prime \prime} \mathrm{W}, 04$ Feb 2012, J. C. O. Santana et al.; UFRGS 25563, 9, 21.2-55.7 mm SL, Ourém, igarapé Tororomba, $01^{\circ} 34^{\prime} 14$ 'S $47^{\circ} 02^{\prime} 27^{\prime \prime} \mathrm{W}, 05$ Feb 2012, J. C. O. Santana et al.; UFRGS 25933, 3, 38.5-50.1 mm SL; 5 c\&s, 38.0-41.4 mm SL, Bragança, sítio JW, 0104’42”S 4644’21'W, 20 Nov 2015, J. Ready.

Non-type material. All from Brazil, Pará: MZUSP 23816, 51, 1 c\&s, $37.3 \mathrm{~mm}$ SL, Paragominas, rio Capim, igarapé Caranaudina, 06 Ago 1970, Expedição Permanente à 
Amazônia. Coastal drainages: MPEG 8224, 9, 12.2-19.2 mm SL, Bragança, 19 Apr 2005, R. Silva; MPEG 8371, 1, 41.8 mm SL, Bragança, Rio Galego, 1 Feb 2005, R. Silva; MPEG 8387, 4, 50.2 mm SL, Bragança, 1 Dec 2005, Kelle; MPEG 18294, 1, 40.1 mm SL, Ourém, igarapé Furo do Novo, 01³4'19'S 4709'42'”W, 17 Nov 2009, B. F. Pamplona; MPEG 21406, 10, 27.8-57.6 mm SL, Marapanim, igarapé Braço Grande de Timboteua, 01 02 '24'S 47³7'21"W, 23 Jul 2010, P. Gerhard; UFRGS 25561, 1, 42.7 mm SL, Tracuateua, igarapé do Meio, vila Mirasselvas, $01^{\circ} 05^{\prime} 56^{\prime}$ 'S 46 ${ }^{\circ} 57^{\prime} 41$ '’W, 07 Feb 2012, J. C. O. Santana et al. Lower rio Xingu, rio Quiã-paranã and rio Anapu: LIA 2233, 11, 17.938.3 mm SL, Vitória do Xingu, 03¹9'31'S 51 '52'18'W, 26 Jul 2014, D. Bastos, A. Martins; LIA 2304, 2, 39.5-46.4 mm SL, Vitória do Xingu, 0305'10”'S 52॰00'36"W, 16 Jul 2014, D. Bastos, A. Martins; LIA 5004, 3, 36.5-47.2 $\mathrm{mm}$ SL, rio Xingu, igarapé, $03^{\circ} 05^{\prime} 10^{\prime}$ 'S 52॰00'36”W, 15 Jul 2015, R. Oliveira; MPEG 7627, 1, 43.5 mm SL, Ponta de Pedras, rio Quiã-paranã, 01²2'09'S48 55'24'W, 18 Dec 2003, A. B. Sousa, V. S. E. Sena; MPEG 10425, 3, 32,55 mm SL, Melgaço, Flona de Caxiuanã, 4 Nov 2004, L. F. A. Montag; MPEG 10442, 1, 30.3 mm SL, Melgaço, Flona de Caxiuanã, $01^{\circ} 45^{\prime}$ S 51 24 'W, 1 Dec 2004, L. F. A. Montag; MPEG 10479, 1, 32.1 mm SL, Melgaço, Flona de Caxiuanã, $01^{\circ} 45^{\prime} 44^{\prime}$ 'S 51 23 '55'W, 29 Nov 2004, L. F. A. Montag; MPEG 11692, 1, 30.1 mm SL, Melgaço, Flona de Caxiuanã, 19 Nov 2003, L. F. A. Montag.

Diagnosis. Pyrrhulina capim differs from all congeners except $P$. australis Eigenmann, Kennedy (Fig. 2a), $P$. brevis Steindachner (Fig. 2b), P. elongata Zarske, Géry
(Fig. 2c), and P. filamentosa Valenciennes (Fig. 2d) by having the primary stripe restricted to the head ( $v s$. primary stripe extending beyond head, reaching the anterior portion of the body but not the vertical through pectoralfin tip in P. eleanorae Fowler (Fig. 2e), P. laeta Cope, $P$. lugubris Eigenmann, $P$. obermulleri Myers (Fig. 2f), $P$. stoli Boeseman (Fig. 2g), P. spilota Weitzman (Fig. 2h), and $P$. vittata Regan; reaching at least the vertical through the pelvic-fin origin, but not reaching the vertical through the anal-fin terminus in $P$. semifasciata Steindachner (Fig. $2 \mathrm{i}$ ) and $P$. maxima Eigenmann, Eigenmann (Fig. $2 \mathrm{j}$ ); or reaching the caudal-fin in $P$. beni Pearson, $P$. marilynae Netto-Ferreira, and P. zigzag Zarske, Géry (Fig. 2k)). Pyrrhulina capim differs from P. australis, P. brevis, $P$. elongata and $P$. filamentosa in that the primary stripe reaches the distal edge of the opercle (vs. stripe restricted to snout and sometimes across eye, but always lacking a conspicuous dark postorbital portion). The new species is further distinguished from $P$. brevis by the number of premaxillary teeth (outer series: 15-20 vs. 25-27; inner series: 24-31 vs. 38-41), and dentary teeth (outer series: 13-20 vs. 22-26; inner series: 32-45 vs. 50-54). Pyrrhulina capim further differs from $P$. australis by having 10 principal rays on the upper caudal-fin lobe (vs. 9 rays); from $P$. filamentosa by possessing fewer scales along the lateral line series (22-25 vs. 25-30); and from P. elongata by having 10-12 scales in the first longitudinal paired series, with that series reaching posterior to the pelvic-fin origin (vs. no more than 6 scales in that series, with that series falling far short of the vertical through the pelvic-fin origin).
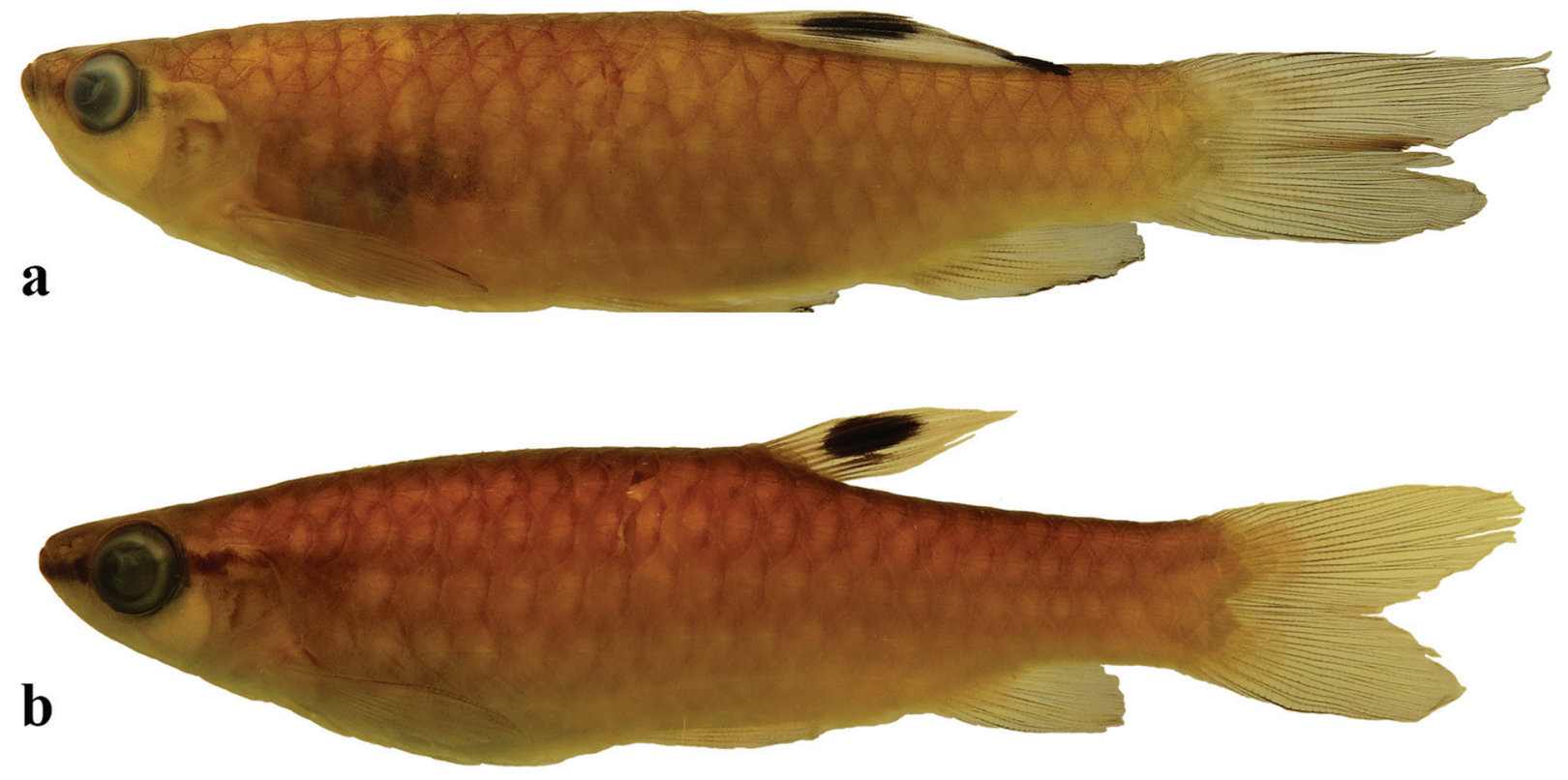

Fig. 1. Lateral view of Pyrrhulina capim, new species, rio São José, Bragança, Pará, Brazil. a. holotype, UFRGS $27300,54.4$ mm SL, male; b. paratype, UFRGS 25562, $40.4 \mathrm{~mm} \mathrm{SL}$, female. 

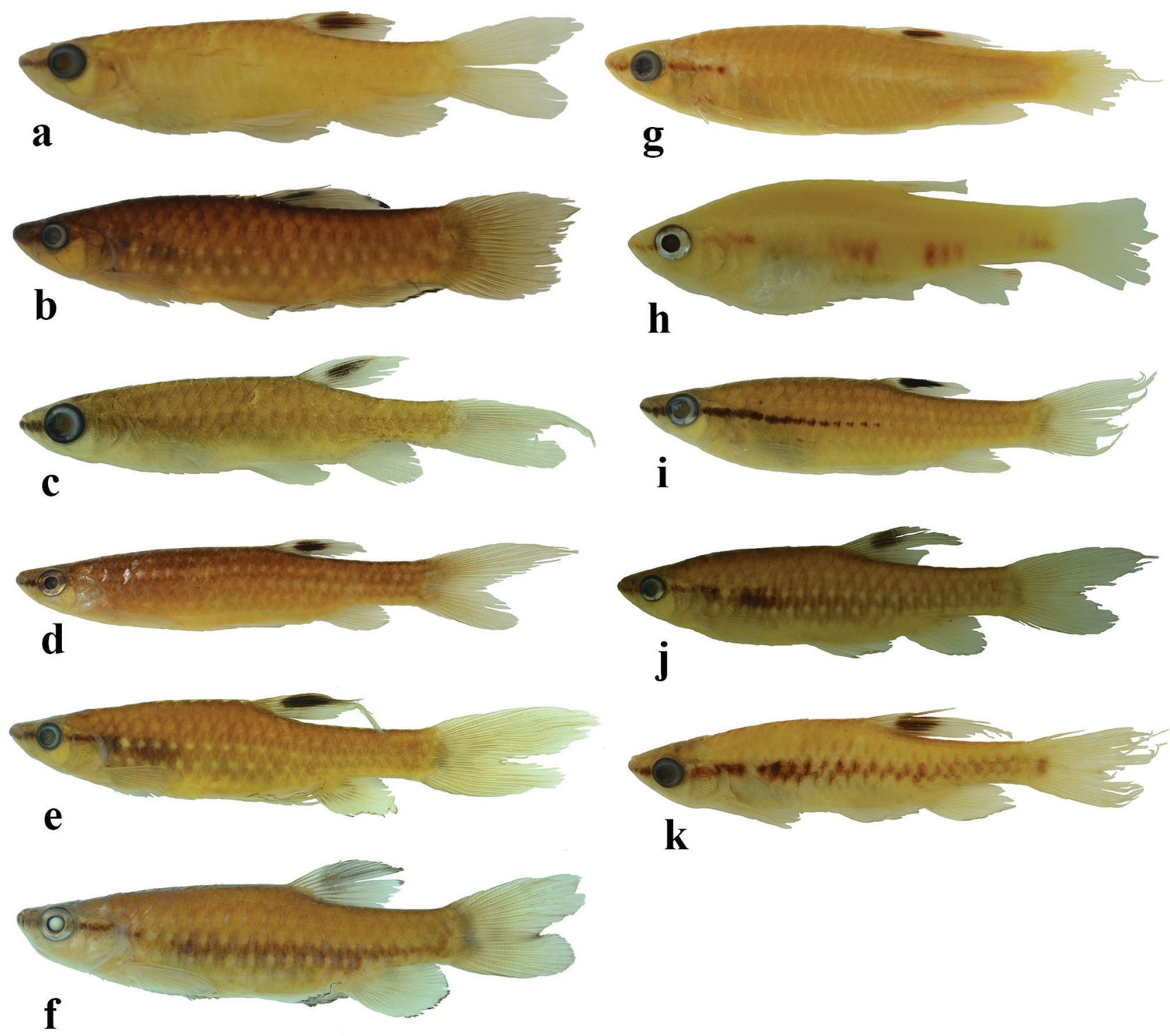

Fig. 2. Lateral view of: a. Pyrrhulina australis, MCP 39259, $38.8 \mathrm{~mm} \mathrm{SL}$, male, Poconé, Mato Grosso, Brazil; b. Pyrrhulina brevis, INPA 27819, $56.3 \mathrm{~mm}$ SL, male, Manaus, Amazonas, Brazil; c. Pyrrhulina elongata, MPEG 26568, $30.6 \mathrm{~mm}$ SL, male, Rio Tapajós, Pará, Brazil; d. Pyrrhulina filamentosa, MHNLS 14282, $59.5 \mathrm{~mm}$ SL, female, Essequibo River, Guiana; e. Pyrrhulina eleanorae, FMNH 113654, 39.7 mm SL, male, Rio Napo, Ecuador; f. Pyrrhulina obermulleri, ANSP 152043, $37.2 \mathrm{~mm}$ SL, male, Maynas, Peru; g. Pyrrhulina stoli, USNM 66254, $60.8 \mathrm{~mm}$ SL, female, upper Potaro river, Guyana; h. Pyrrhulina spilota, USNM 197523, $52.7 \mathrm{~mm}$ SL, male, Loreto, Peru; i. Pyrrhulina semifasciata, MCP 37466, $56.7 \mathrm{~mm}$ SL, female, Loreto, Peru; j. Pyrrhulina cf. maxima, MPEG 19120, 50.4 mm SL, male, Rio Amazonas, Brazil; k. Pyrrhulina zigzag, FMNH 94556, 35.6 mm SL, male, Rio Napo, Ecuador.

Description. Morphometric data of the holotype and 60 paratypes presented in Tab. 1. Lateral view of male holotype and female paratype in Fig. 1a and Fig. 1b, respectively. Body cylindrical, slightly elongate. Greatest body depth anterior to dorsal-fin origin, between pectoral and pelvic fins. Dorsal profile of head straight, slightly concave from upper lip to anterior scales covering parietal and supraoccipital. Dorsal profile of body slightly convex or nearly straight from that point to dorsal-fin origin; gently concave along dorsal-fin base and caudal peduncle near vertical through anal-fin terminus, becoming nearly straight from that point to origin of anterodorsal procurrent ray of caudal fin. Ventral profile of head and trunk convex from lower lip to pelvicfin origin, becoming straight from that point to anal-fin origin. In male specimens, anal-fin base slightly convex, caudal peduncle straight or slightly concave from that point to origin of anteroventral procurrent ray of caudal fin. In female specimens, ventral profile of anal-fin base and caudal peduncle gently concave to origin of anteroventral procurrent ray of caudal fin. 
Tab. 1. Morphometric data of the holotype and paratypes of Pyrrhulina capim, new species. SD = Standard Deviation.

\begin{tabular}{|c|c|c|c|c|c|c|c|c|c|c|c|c|}
\hline \multirow{3}{*}{$\begin{array}{l}\text { Paratypes } \\
\text { SL }\end{array}$} & \multirow{3}{*}{$\begin{array}{c}\text { Holotype } \\
54.4\end{array}$} & \multirow{3}{*}{$\begin{array}{c}\mathrm{n} \\
60\end{array}$} & \multicolumn{5}{|c|}{ Males } & \multicolumn{5}{|c|}{ Females } \\
\hline & & & \multicolumn{3}{|c|}{ Range } & \multirow{2}{*}{$\begin{array}{c}\text { Mean } \\
47.1\end{array}$} & \multirow[t]{2}{*}{ SD } & \multicolumn{3}{|c|}{ Range } & \multirow{2}{*}{$\begin{array}{c}\text { Mean } \\
34.3\end{array}$} & \multirow[t]{2}{*}{$\mathrm{SD}$} \\
\hline & & & 39.7 & - & 57.7 & & & 12.3 & - & 57.7 & & \\
\hline Depth dorsal fin origin & 24.3 & 53 & 21.5 & - & 29.0 & 24.9 & 1.4 & 21.9 & - & 27.7 & 24.5 & 1.4 \\
\hline Snout to anal fin origin & 75.5 & 53 & 72.4 & - & 77.7 & 75.2 & 1.4 & 74.0 & - & 78.5 & 76.5 & 1.2 \\
\hline Snout to pelvic fin origin & 49.4 & 53 & 47.1 & - & 53.7 & 50.6 & 1.7 & 47.7 & - & 54.5 & 52.1 & 1.4 \\
\hline Snout to dorsal fin origin & 57.4 & 53 & 56.9 & - & 62.3 & 59.1 & 1.7 & 59.1 & - & 62.8 & 60.7 & 0.9 \\
\hline Dorsal fin origin to caudal base & 44.8 & 53 & 39.9 & - & 45.6 & 42.6 & 1.5 & 39.7 & - & 44.2 & 41.7 & 1.1 \\
\hline Dorsal fin length & 33.9 & 52 & 26.7 & - & 34.1 & 29.9 & 2.2 & 21.6 & - & 30.5 & 25.7 & 1.8 \\
\hline Length caudal peduncle & 13.3 & 53 & 11.9 & - & 15.4 & 13.4 & 0.9 & 11.7 & - & 18.9 & 14.0 & 1.5 \\
\hline Depth caudal peduncle & 13.9 & 52 & 12.9 & - & 16.1 & 14.3 & 0.9 & 11.0 & - & 13.8 & 12.8 & 0.6 \\
\hline Anal fin length & 24.1 & 53 & 20.1 & - & 25.1 & 23.4 & 1.3 & 18.0 & - & 23.2 & 20.6 & 1.2 \\
\hline Anal fin base & 11.9 & 53 & 10.8 & - & 14.0 & 12.3 & 0.7 & 8.3 & - & 13.4 & 10.3 & 1.2 \\
\hline Pelvic to anal fin origin & 28.9 & 53 & 23.1 & - & 28.9 & 25.9 & 1.4 & 22.8 & - & 29.9 & 25.2 & 1.5 \\
\hline Pelvic fin length & 25.7 & 53 & 19.4 & - & 27.7 & 23.6 & 2.4 & 17.2 & - & 22.5 & 19.9 & 1.2 \\
\hline Pectoral to pelvic fin origin & 27.2 & 53 & 25.4 & - & 29.1 & 27.0 & 1.0 & 23.3 & - & 31.6 & 26.9 & 1.8 \\
\hline Pectoral fin length & 22.3 & 53 & 20.7 & - & 24.9 & 22.5 & 1.2 & 17.0 & - & 25.8 & 22.6 & 1.7 \\
\hline Snout to pectoral fin origin & 24.1 & 53 & 22.2 & - & 26.3 & 24.1 & 0.8 & 23.8 & - & 28.4 & 26.2 & 1.4 \\
\hline Head length & 26.0 & 53 & 23.8 & - & 28.9 & 25.9 & 1.1 & 24.9 & - & 29.6 & 27.2 & 1.4 \\
\hline Horizontal eye diameter & 29.4 & 53 & 28.2 & - & 34.0 & 31.3 & 1.7 & 29.1 & - & 39.4 & 33.2 & 2.2 \\
\hline Distance snout to eye & 31.4 & 53 & 28.1 & - & 32.2 & 30.6 & 1.1 & 25.0 & - & 33.2 & 29.5 & 2.2 \\
\hline Interorbital distance & 38.8 & 53 & 36.7 & - & 42.5 & 39.4 & 1.5 & 35.7 & - & 43.7 & 39.5 & 1.8 \\
\hline Upper jaw length & 20.5 & 53 & 18.7 & - & 26.6 & 21.9 & 2.4 & 16.6 & - & 24.2 & 20.4 & 2.0 \\
\hline Lower jaw length & 36.5 & 53 & 26.4 & - & 36.5 & 32.7 & 2.4 & 26.6 & - & 44.0 & 32.1 & 3.2 \\
\hline
\end{tabular}

Mouth superior. Premaxillary with two series of conical teeth; outer series with $15(3), 17(1), 18(2), 19(5)$ or $20(1)$ teeth; inner series with 24(2), 25(1), 26(3), 28(2), 30(2), or $31(2)$ teeth. Maxillary with 11(1), 14(1), 15(1), 16(1), 18(1) or 19(1) conical teeth in males, and 7(1),8(1),9(3) or 10(1) in females, anterior teeth largest in both sexes. Dentary with two series of conical teeth; outer series with 13(1), 14(2), $15(1), 16(3), 17(1), 18(2)$, or 20(2); inner series with 32(2), $33(1), 34(1), 35(1), 37(2), 38(1), 42(1), 43(1), 44(1)$ or $45(1)$. Inner series of teeth gradually decreasing in size from symphysis to near coronoid process. Lower jaw protruding slightly beyond premaxillary. Branchiostegal rays 3; two articulating with anterior ceratohyal and one with posterior.

Scales cycloid, circuli restricted to anterior border, few radii converging and strongly anastomosed at focus, not forming cells. Lateral line series with 22(3), 23(25), $24 *(19)$ or $25(1)$ scales; none perforated. Longitudinal series of scales between dorsal and pelvic fins 5. Predorsal scales 10(1), 11(6), 12*(22), 13(21) or 14(1). First paired longitudinal series with $9(2), 10(12), 11 *(23), 12(11)$ or 13(2) scales. Circumpeduncular scales $10 *$.

Pectoral-fin rays $i, 10(5), i, 11 *(18)$ or i,12(30). Tip of longest pectoral-fin ray falling far short of vertical through pelvic-fin origin. Pelvic-fin rays i, $7 *(52)$ or i,8(1); tip of longest pelvic-fin ray reaching anal-fin origin in adult males, but not in juveniles or females. Supraneurals 7(12), positioned anterior to neural spines of centra 7(12) to 13(12). First dorsal-fin pterygiophore inserted posterior to neural spine of centrum 12(3), 13(8) or 14(1). Dorsal-fin rays ii,6(1), iii,6(6), iii,7(2) or ii, $8^{*}(48)$. Distal margin of extended dorsal fin somewhat rounded in females, lanceolate in adult males. Dorsal-fin origin located distinctly closer to caudal fin than to snout tip. Base of last dorsal-fin ray located at vertical through anal-fin origin. Anal-fin rays iii,8(37) or ii, $8 *(16)$, with last ray adnate. Profile of extended anal fin rounded in females, somewhat elliptical or lanceolate in males. First anal-fin pterygiophore inserted posterior to haemal arch of centrum 19(8) or 20(4). Adipose fin absent. Caudal fin forked, upper lobe distinctly longer. Caudal-fin principal rays ii, $8 / 7, \mathrm{i}(1), \mathrm{ii}, 8 / 7, \mathrm{ii}(8), \mathrm{ii}, 8 / 8, \mathrm{i}^{*}(26), \mathrm{i}, 9 / 7, \mathrm{ii}(2)$, $\mathrm{i}, 9 / 8, \mathrm{i}(13)$ or ii,9/8,i(1). Dorsal caudal-fin procurrent rays 4(12). Ventral caudal-fin procurrent rays 4(5) or 5(7). Precaudal vertebrae 17(7) or 18(5); caudal vertebrae 14(3), 15(6) or $16(3)$.

Color in alcohol. Background color yellowish. Dorsal portion of head light brown from the upper lip to scales overlying parietal bone. Lateral surfaces of head distinctly lighter than dorsum, with dark pigmentation becoming abruptly scarce ventral to primary stripe. Primary stripe heavily pigmented and restricted to the head, pigmenting both jaws, antorbital, infraorbitals 1 and 5 and eye, and reaching posterior margin of opercle or opercular membrane. Ventral portion of head with few, scattered chromatophores. Mid-dorsal, first and second longitudinal series of scales with light brown pigmentation, becoming 
slightly darker at dorsal-fin base and extending to caudalpeduncle tip. Trunk pigmentation lighter ventrally to third longitudinal series of scales. Scale borders of second and third longitudinal series with discrete, dark pigmentation on edges, homogeneously pigmented near foci, not forming distinct reticulate pattern. Scales of fourth to sixth longitudinal series somewhat pale at focus, with discrete guanine deposition, forming longitudinal series of pale blotches (ranging from yellow to red in life). Abdominal region yellowish with sparse dark chromatophores from isthmus to anal-fin origin. Pectoral fin completely hyaline. Pelvic and anal fins mostly hyaline except for pigmented distal margin in males (see sexual dimorphism). Caudal fin hyaline with scarce chromatophores. Dorsal fin with round blotch at mid-distal portion covering all branched and unbranched rays and intervening membranes.

Sexual dimorphism. Adult males of Pyrrhulina capim possess the typical sexual dimorphism of Lebiasinidae (Netto-Ferreira et al., 2011; Netto-Ferreira, Marinho, 2013), in which the anal-fin rays and all intervening membranes are distinctly thicker and longer than in females, ultimately resulting in broader anal fins in male specimens (Marinho, Menezes, 2017). Male specimens possess more maxillary teeth than females (11-18 vs. 7-10, respectively). Adult males have dark pigmentation at the distal margin of the anal and pelvic fins that forms a discrete dark band. Pelvic fin of males distinctly longer than those of females. Dorsal-fin of adult males with distinctly elongate dark blotch ( $v s$. ovoid or round blotch in females), extending throughout the median and distal portions of first and second branched rays. Caudal peduncle of adult males usually deeper than in females (12.9\%-15.1\% vs. 11.0\%-13.8\%; Fig. 3).

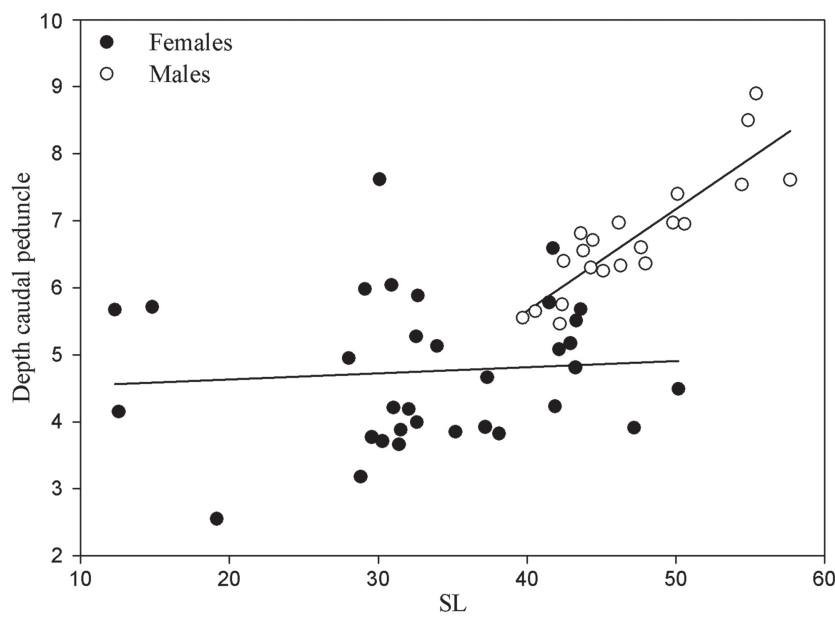

Fig. 3. Scatterplot of caudal peduncle depth versus SL in males and females of Pyrrhulina capim, new species. Lines represent the $95 \%$ confidence intervals.

Geographical distribution. Pyrrhulina capim is known from the Eastern Amazon, in northern Brazil from the basins of the rio Anapu, rio Capim, rio Guamá, lower rio Xingu, and coastal drainages of the Amazon estuary in the state of Pará (Fig. 4).

Ecological notes. Pyrrhulina capim inhabits the banks of rivers and streams of clear water with moderate flow, sandy substrate and submerged vegetation.

Etymology. The epithet capim (from the indigenous language Tupi-Guarani meaning: Caá $=$ leaf; Pií $=$ thin, slender) alludes to the rio Capim, a tributary of the rio Guamá, where the first specimens examined by ALN-F were collected. A noun in apposition.

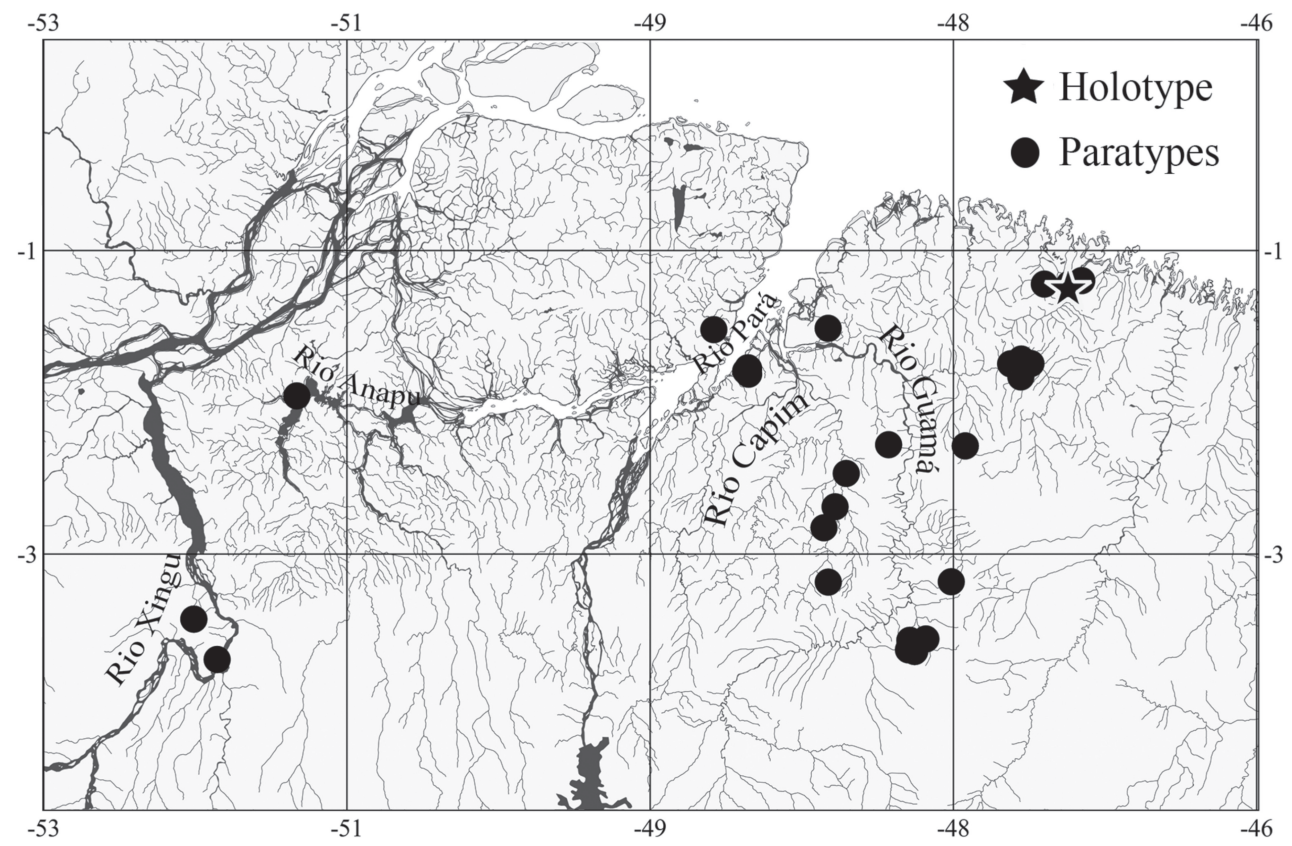

Fig. 4. Map of northern portion of South America, with the distribution of Pyrrhulina capim, new species. The polygons represent the localities of the holotype and paratypes. 
Conservation status. Despite all the human impacts in the known area of occurrence of Pyrrhulina capim (i.e., deforestation, mining activities, palm tree plantations, cattle activities, among others), there is no information on whether those activities impact populations of that species. That said, P. capim, has a relatively broad distribution in the Floresta Nacional de Caxiuanã, and possibly in other protected areas such as the Reserva Extrativista (=Resex) Gurupá-Melgaço, Resex Terra Grande-Pracuúba, and protected areas in the upper rio Guamá. Because of that broad area of occurrence (see distribution), it is likely that Pyrrhulina capim can be classified as a species of Least Concern (LC) according to the International Union for Conservation of Nature (IUCN) categories and criteria (IUCN Standards and Petitions Subcommittee, 2017).

Remarks. Pyrrhulina capim shares with all congeners the generic synapomorphies indicated by Netto-Ferreira (2010): the presence of two series of premaxillary teeth; the lack of postcleithrum 3; the dorsalmost, paired longitudinal series of scales not reaching posterior to the dorsal-fin origin; and the coronomeckelian bone approximately ten times shorter than Meckelian cartilage. Despite sharing a short primary stripe with $P$. australis, $P$. brevis, P. elongata and P. filamentosa, it is not currently clear whether $P$. capim is more closely related to those four species than to other species of Pyrrhulina, because no phylogenetic hypotheses for the genus exists. That said, the characters discussed by Netto-Ferreira, Marinho (2013) - (i.e., the reduction of the number of precaudal vertebrae; the presence of 9 caudal-fin principal rays on the upper lobe; the absence of postcleithrum 2; and the lack of filamentous rays on dorsal) suggest that $P$. australis may share a closer relationship with other small species of Pyrrhulina, such as P. marilynae, $P$. vittata and $P$. zigzag.

Specimens of Pyrrhulina capim have been commonly identified as Pyrrhulina brevis in the literature (Montag et al., 2008; 2009; Raiol et al., 2012; Silva-Oliveira et al., 2016; Ferreira et al., 2018) and in many collections. Such identifications seem to have been induced by the broad definition of the Pyrrhulina brevis-group proposed by Géry (1977). According to that definition, the P. brevis-group includes deep bodied species with low longitudinal scale counts (20-23), and a short primary stripe restricted to the eye or the opercle. That "diagnosis" fits not only P. brevis, but also most stout bodied, short striped species of the genus such as $P$. australis, $P$. brevis, $P$. capim, $P$. lugubris, and $P$. obermulleri. In that contribution Géry suggested the possibility that these forms instead of distinct species would represent variations within a single, widespread species "with slightly divergent characters," contradicting his own observations in a previous study (Géry, 1972). The subsequent descriptions of Pyrrhulina zigzag, originally recognized among the syntypes of $P$. brevis (Zarske, Géry, 1997) and P. elongata, a species with short primary stripe but low body depth (Zarske, Géry, 2001) have weakened the case for a single, widespread Pyrrhulina brevis. Similarly, the likely erroneous synonymy of $P$. rachoviana with P. australis (Zarske, Géry, 2004), which represents another operational group in the genus indicates substantial imprecision in Géry's (1977) group definitions, and suggests a substantial lack of evidence for their reality. Hence, the recognition and usage of such "groups" may be misleading, and they should be abandoned until broad phylogenetic and revisionary studies are available for the genus.

Comparative material examined. In addition to the specimens listed in Netto-Ferreira et al. (2011), Netto-Ferreira (2012), Netto-Ferreira, Marinho (2013) and Netto-Ferreira et al. (2013), the following specimens were examined. Pyrrhulina australis: MCP 10675, 2, 22.4-39.0 mm SL; MPEG 16997, 4 c\&s, 32.1-36.6 mm SL; MCP 37466, 18, 15.1-56.7 mm SL; MCP 38118, 55, 21.0-29.7 mm SL; MCP 39183, 2, 11.5-24.1 mm SL; MCP 39240, 2, 18.3-41.3 mm SL; MCP 39277, 55, 18.7-30.2 mm SL; MCP 40882 2, 13.0-30.7 mm SL. Pyrrhulina brevis: INPA 25993, 1, 33.9 mm SL; INPA 25999, 1, 29.0 mm SL; INPA 26019, 5, 14.3-29.2 mm SL; INPA 26024, 24, 15.2-68.8 mm SL; INPA 26033, 2, 16.2-27.0 mm SL; INPA 26040, 1, $54.3 \mathrm{~mm}$ SL; INPA 26042, 19, 15.7-61.1 mm SL; INPA 26048, 3, 22.1-42.0 mm SL; INPA 26052, 2, 43.9-60.8 mm SL; INPA 27819, 134, 12.167.4 mm SL, 2 c\&s; INPA 31528, 18, 30.1-64.4 mm SL. Pyrrhulina elongata: MPEG 25182, 2, 20.5-23.6 mm SL; MPEG 26568, 2, 23.830.6 mm SL; MPEG 26685, 1, 32.5 mm SL; MPEG 26687, 1, 30.9 mm SL; MPEG 27799, 6, 16.6-22.6 mm SL; MPEG 27844, 1, 31.0 mm SL; MPEG 28403, 4, 13.9-19.1 mm SL; MPEG 28446, 35, 13.224.3 mm SL; MPEG 28469, 2, 25.3-29.1 mm SL; MPEG 28482, 2 , 20.9-25.8 mm SL; MPEG 28533, 4, 17.9-23.7 mm SL; MPEG 28590, 2, 17.4-26.0 mm SL; MPEG 28657, 1, 17.6 mm SL; MPEG 28685, 3, 15.6-20.5 mm SL; MPEG 28748, 2, 21.2-23.1 mm SL. Pyrrhulina filamentosa: FMNH 53439, 5, 39.0-49.9 mm SL; MBUCV 5978, 4, 35.5-52.4 mm SL; MHNLS 14271, 10, 42.2-50.9 mm SL; MHNLS 14282, 10, 52.7-75.6 mm SL, 2 c\&s; USNM 66254, 5, 29.9-67.8 mm SL. Pyrrhulina laeta: FMNH 94558, 20, 24.5-38.4 mm SL; FMNH 113654, 20, 27.4-61.2 mm SL. Pyrrhulina lugubris: CAS 78889, 2, 38.7-40.2 mm SL. Pyrrhulina marilynae: ANSP 199222, 2, 26.3-26.7 mm SL. Pyrrhulina obermulleri: ANSP 152043, 3, 20.5-32.1 mm SL; ANSP 167231, 3, 29.1-37.1 mm SL. Pyrrhulina semifasciata: MCP 37466, 18, 16.3-55.9 mm SL. Pyrrhulina spilota: USNM 197523, 17, 14.9-52.7 mm SL. Pyrrhulina stoli: ANSP 175475, 9, 19.1-41.6 mm SL; ANSP 176763, 40, 22.8-44.3 mm SL; ANSP 176764, 30, 21.3$42.1 \mathrm{~mm}$ SL; ANSP 176765, 20, 24.9-46.8 mm SL; ANSP 201969 , 10, 21.6-40.6 mm SL; FMNH 53432, 5, 44.6-64.5 mm SL; FMNH 69736, 15, 27.0-48.3 mm SL. Pyrrhulina zigzag: FMNH 94556, 20, 13.7-32.5 mm SL; MPEG 5795, 3, 24.3-32.7 mm SL. Pyrrhulina sp.: ANSP 128968, 10, 28.0-37.9 mm SL; ANSP 128969, 5, 14.3-33.9 mm SL; ANSP 128975, 3, 34.4-41.5 mm SL; ANSP 135694, 15, 35.446.7 mm SL; ANSP 137624, 4, 44.9-60.1 mm SL; ANSP 141569, 40, 17.9-40.2 mm SL; INPA 26006, 1, 45.4 mm SL; MCP 26213, 2, 22.229.9 mm SL; MCP 38699, 25, 20.4-29.2 mm SL; MCP 38748, 13, 22.4-31.3 mm SL; MCP 40684, 25, 22.1-29.4 mm SL; MCP 40714, 24, 15.6-25.9 mm SL; MCP 40745, 17, 21.2-33.5 mm SL; MCP 40803, 25, 27.2-33.1 mm SL; MCP 40876, 24, 17.6-32.4 mm SL; MCP 40884, 25, 15.9-23.4 mm SL; MPEG 8216, 2, 32.0-40.7 mm SL; MPEG 10088, 2 c\&s, 41.9-44.8 mm SL; MPEG 12149, 3, 35.248.4 mm SL; MPEG 15330, 1, 36.6 mm SL; MPEG 15345, 1, 36.5 
mm SL; MPEG 30581, 2, 11.0-60.9 mm SL; MPEG 18214, 2, 16.5 44.8 mm SL; USNM 261426, 10, 23.9-34.7 mm SL; USNM 261434, 5, 23.2-33.3 mm SL.Pyrrhulina sp1.: MBUCV 33341, 4, 49.3-57.9 mm SL; MBUCV 33344, 4, 42.2-49.3 mm SL, 2 c\&s; MCNG 1521, 15, 35.2-41.9 mm SL; MBUCV 16682, 4, 39.2-47.5 mm SL, 2 c\&s; MBUCV 35223, 5, 34.0-39.4 mm SL; MBUCV 34995, 4, 40.2-44.8 mm SL). Pyrrhulina sp2.: MBUCV 18648, 4, 44.2-61.7 mm SL, 2 c\&s; MBUCV 19759, 6, 45.6-69.5 mm SL). Pyrrhulina sp3.: MCNG 25770, 15, 35.0-40.2 mm SL, 1 c\&s; MCNG 27823, 5, 34.6-40.2 mm SL; MCNG 25640, 10, 33.5-37.6 mm SL, 1 c\&s.

\section{Acknowledgments}

Thanks are due to Wolmar Wosiacki (MPEG) and Luiz Malabarba (UFRGS) for providing facilities for the conduction of the present study. The authors are also thankful to other collections and their staff for loans of the comparative material used in the present study: Mark Henry Sabaj Pérez (ANSP), Dave Catania (CAS), Caleb McMahan (FMNH), Lúcia Helena Rapp Py-Daniel (INPA), Leandro Sousa (LIA), Francisco Provenzano (MBUCV), Otto Castillo (MCNG), Carlos Lucena (MCP), Oscar Lasso (MHNLS) and Jeff Williams (USNM). The authors were financially supported by CNPq (Conselho Nacional de Desenvolvimento Científico e Tecnológico; proc. $\mathrm{n}^{\circ} 133586 / 2017-0$ and proc. $\mathrm{n}^{\circ} 313404 / 2015-1$ ).

\section{References}

Eigenmann $\mathrm{CH}$. The fishes of western South America. Part I: The fresh-water fishes of northwestern South America, including Colombia, Panama, and the Pacific slopes of Ecuador and Peru, together with an appendix upon the fishes of the rio Meta in Colombia. Mem Carnegie Mus. 1922; 9(1):1-346.

Eigenmann CH, Eigenmann RS. A review of the Erythrininae. Proc Calif Acad Sci. 1889; 2(2):100-16.

Ferreira MC, Begot TO, Prudente BS, Juen L, Montag LFDA. Effects of oil palm plantations on habitat structure and fish assemblages in Amazon streams. Environ Biol Fishes. 2018; 101(4):547-62.

Fink WL, Weitzman SH. The so-called Cheirodontin fishes of Central America with description of two new species (Pisces: Characidae). Washington (DC): Smithsonian Institution Press; 1974. (Smithsonian Contributions to Zoology; No. 172).

Fowler HW. A collection of fishes obtained by Mr. William C. Morrow in the Ucayali River basin, Peru. Proc Acad Nat Sci Philadelphia. 1940; 91:219-89.

Fricke R, Eschmeyer WN, Fong JD. Eschmeyer's catalog of fishes: species by family/subfamily [Electronic version]. San Francisco (CA): California Academy of Sciences; 2019. Available from: http://researcharchive.calacademy.org/research/ichthyology/ catalog/SpeciesByFamily.asp

Géry J. Corrected and supplemented descriptions of certain characoid fishes described by Henry W. Fowler, with revisions of several of their genera. Stud Neotrop Fauna. 1972; 7(1):1-35.

Géry J. Characoids of the world. Neptune City: T. F. H. Publications; 1977.

Géry J, Zarske A. Derhamia hoffmannorum gen. et sp. n. -a new pencil fish (Teleostei, Characiformes, Lebiasinidae), endemic from the Mazaruni River in Guyana. Zool Abh. 2002; 52(1):35-47.

International Union for Conservation of Nature (IUCN). Standards and Petitions Subcommittee. Guidelines for Using the IUCN
Red List Categories and Criteria. Version 13 [Internet]. 2017. Available from: http://www.iucnredlist.org/documents/ RedListGuidelines.pdf/

Marinho MMF, Menezes NA. Taxonomic review of Copella (Characiformes: Lebiasinidae) with an identification key for the species. PLoS ONE. 2017; 12(8):e0183069.

Montag LFDA, Albuquerque AA, Freitas TMDS, Barthem RB. Ictiofauna de campos alagados da Ilha do Marajó, Estado do Pará, Brasil. Biota Neotrop. 2009; 9(3):241-53.

Montag LFDA, Freitas TMDS, Wosiacki WB, Barthem RB. Os peixes da Floresta Nacional de Caxiuanã (municípios de Melgaço e Portel, Pará-Brasil). Bol Mus Para Emílio Goeldi, Ciências Naturais. 2008; 3(1):11-34.

Netto-Ferreira AL. Revisão taxonômica e relações interespecíficas de Lebiasininae (Ostariophysi: Characiformes: Lebiasinidae). [PhD Thesis on the Internet]. São Paulo, SP: Universidade de São Paulo; 2010.

Netto-Ferreira AL. Three new species of Lebiasina (Characiformes: Lebiasinidae) from the Brazilian Shield border at Serra do Cachimbo, Pará, Brazil. Neotrop Ichthyol. 2012; 10(3):487-98.

Netto-Ferreira AL, Lopez-Fernandez H, Taphorn DC, Liverpool EA. New species of Lebiasina (Ostariophysi: Characiformes: Lebiasinidae) from the upper Mazaruni River drainage, Guyana. Zootaxa. 2013; 3652(5):562-68.

Netto-Ferreira AL, Marinho MMF. New species of Pyrrhulina (Ostariophysi: Characiformes: Lebiasinidae) from the Brazilian Shield, with comments on a putative monophyletic group of species in the genus. Zootaxa. 2013; 3664(3):369-76.

Netto-Ferreira AL, Oyakawa OT, Zuanon J, Nolasco JC. Lebiasina yepezi, a new Lebiasininae (Characiformes: Lebiasinidae) from the Serra Parima-Tapirapecó mountains. Neotrop Ichthyol. 2011; 9(4):767-75.

Raiol RDO, Wosiacki WB, Montag LFDA. Fish of the Taiassui and Benfica river basins, Benevides, Pará (Brazil). Check List. 2012; 8(3):491-98.

Silva-Oliveira C, Canto ALC, Ribeiro FRV. Stream ichthyofauna of the Tapajós National Forest, Pará, Brazil. ZooKeys. 2016; 580:125-44.

Taylor WR, Van Dyke GC. Revised procedures for staining and clearing small fishes and other vertebrates for bone and cartilage study. Cybium. 1985; 9(2):107-19.

Weitzman SH. The osteology of Brycon meeki, a generalized characid fish, with an osteological definition of the family. Stanford Ichthyol Bull. 1962; 8(1):1-77.

Weitzman SH. Review of South American characid fishes of subtribe Nannostomina. Proc U S Natl Mus. 1966; 119:1-35.

Weitzman M, Weitzman SH. Family Lebiasinidae (Pencil fishes). In: Reis RE, Kullander SO, Ferraris CF, Jr., editors. Check list of the freshwater fishes of South and Central America. Porto Alegre: Edipucrs; 2003. p.241-250.

Zarske A, Géry J. Ein neuer Salmler aus Peru, Pyrrhulina zigzag sp. n. (Pisces: Teleostei: Lebiasinidae). Das Aquarium. 1997; 31(336):12-17.

Zarske A, Géry J. Pyrrhulina elongata sp. n. - ein neuer Salmler aus dem Einzugsgebiet des rio Tapajós in Brasilien (Teleostei: Characiformes: Lebiasinidae). Zool Abh. 2001; 51(2):15-21.

Zarske A, Géry J. Zur Variabilität von Pyrrhulina australis Eigenmann \& Kennedy, 1903 (Teleostei: Characiformes: Lebiasinidae). Zool Abh. 2004; 54:39-54. 